\title{
Leaching of selected metals from a landfill of the closed down Siersza coal mine in Trzebinia (S Poland) ${ }^{1}$
}

\author{
Ocena testu wymywalności wybranych metali z odpadów \\ wydobywczych węgla kamiennego zlikwidowanej kopalni \\ „Siersza” w Trzebini (Polska S)
}

${ }^{*} \mathrm{Dr}$ hab. inż. Alicja Kicińska, mgr inż. Beata Kosa - AGH University of Science and Technology, Faculty of Geology, Geophysics and Environmental Protection, Mickiewicza 30 av., 30-059 Kraków, e-mail: kicinska@geol.agh.edu.pl; beata.kosa@wp.pl

Keywords: leaching, coal waste, heavy metals, Trzebinia

Słowa kluczowe: wymywanie wodne, odpady górnictwa węglowego, metale ciężkie

\begin{abstract}
Landfills of waste generated by coal mining could pose a serious environmental threat if not properly reclaimed. The study focuses on leaching select heavy metals from the waste disposed of by the closed down Siersza hard coal mine in Trzebinia (SilesianCracow area). The solid waste samples were analysed with the X-ray fluorescence (XRF) method for $\mathrm{Zn}, \mathrm{Pb}, \mathrm{Cd}, \mathrm{Mn}$ and Fe contents. The eluates were obtained by leaching the solid samples with distilled water at the ratio 1:10 and analysed with the atomic absorption spectroscopy (AAS) method. The most prone for leaching were $\mathrm{Mn}$ and $\mathrm{Zn}$ (78 and $73 \%$ of the total contents), the medium prone $\mathrm{Pb}$ and $\mathrm{Cd}$ (around 50\% each), and the least prone $\mathrm{Fe}(30 \%)$. In the western part of the landfill, zinc occurs in unexpectedly high amounts (0.64-3.3 wt.\%), which may be related to the presence of slag of unknown provenience. The concentrations of $\mathrm{Zn}, \mathrm{Pb}$ and $\mathrm{Cd}$ (averages in $\mathrm{mg} \cdot \mathrm{kg}^{-1}$ : 6727, 2.3 and 10.3 , respectively) in the leachates exceed the limits of Polish environmental standards. The landfill should be properly monitored and fully reclaimed.
\end{abstract}

(C) IOŚ-PIB

\section{INTRODUCTION}

Coal mining as an industrial sector generates the largest amounts of waste [GUS 2015]. Currently, about $81.6 \%$ of waste from the extraction of bituminous coal and lignite in Poland is recovered and reused, whereas the remaining part is disposed of on landfills. At the end of 2014, the amount of waste resulting from coal mining and cleaning exceeded 460.8 million $\mathrm{Mg}$ [GUS 2015] and such a massive volume may have a negative impact on the environment [Czop, Kajda-Szcześniak 2013; Galos, Szlugaj 2014]. Barren rocks and the coals themselves contain heavy metals, e.g. $\mathrm{Zn}, \mathrm{Pb}, \mathrm{Mn}, \mathrm{Cd}$ and $\mathrm{Hg}$, as well as radioactive elements [Klojzy-Karczmarczyk, Mazurek 2010]. Inappropriate protection of landfills, especially those belonging to abandoned mines, can result in mobilisation of toxic compounds

This paper was supported by AGH grant no. BS 11.11.140.199

\section{Streszczenie}

Składowiska odpadów z górnictwa węgla kamiennego z uwagi na ich ilość mogą stanowić poważne zagrożenie dla środowiska. Przedmiotem przeprowadzonych badań była ocena wymywalności wybranych metali ciężkich z odpadów górnictwa węgla kamiennego przy zastosowaniu testu wymywania w stosunku fazy stałej do roztworu 1:10. Zostały przebadane próbki z odpadów ze zlikwidowanej Kopalni Węgla Kamiennego „Siersza” w Trzebini. Za pomocą metody XRF oznaczono zawartość całkowitą badanych pierwiastków ( $\mathrm{Zn}, \mathrm{Pb}, \mathrm{Cd}, \mathrm{Mn}$, $\mathrm{Fe}$ ), a ilości pierwiastków wymytych z odpadów określono za pomocą AAS. Na podstawie uzyskanych wyników stwierdzono, że w najłatwiej z odpadów wymywane są Mn oraz Zn (78 i 73\% zawartości całkowitej), średnio podatne $\mathrm{Pb}$ i Cd (ok. 50\%), a najtrudniej wymywane jest $\mathrm{Fe}(30 \%)$. Ponadto w zachodniej części opróbowanego składowiska zauważono wysoką koncentrację Zn, która najprawdopodobniej związana jest z obecnością żużli pohutniczych, które znajdują się w pobranych próbkach odpadów. and elements, mainly by leaching and/or blowing away the fine material. The effluents from landfills are the source of water and soil acidification, caused mainly by weathering of pyrite contained in coal waste (acid drainage), and are a threat to proximal and/ or distal ecosystems. Such a situation can be observed in the Trzebinia commune, which was up to early 2000 s the site of large plants of the mining, chemical and energy sectors. These industrial operations included the Siersza coal mine, the Siersza power station, the Trzebionka mine of $\mathrm{Zn}-\mathrm{Pb}$ ores, metallurgical works, a plant of refractory materials and an oil refinery, practically all located within the Trzebinia town borders. Prior to 1954, the Górka quarry provided marls and limestones for a local cement plant (the later producer of the refractories). Currently, the number of larger plants in Trzebinia is limited to the oil refinery, the power station and the ceramic works, but the remains of 


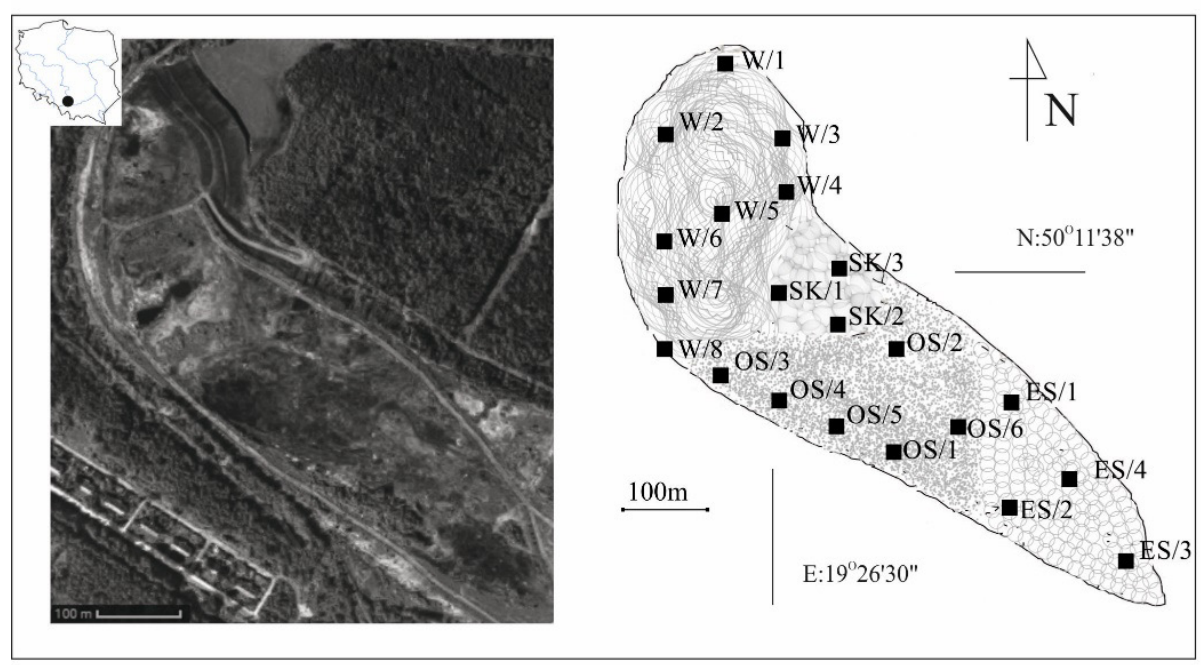

Figure 1. Sampling site.

older operations are still found in landfills and quarrying sites [Pasieczna et al. 2008; Kot-Niewiadomska 2013].

The authors present preliminary results of a study on the landfill of waste accumulated by the Siersza coal mine that focused on the following aspects:

- The total content of five selected elements: $\mathrm{Zn}, \mathrm{Pb}, \mathrm{Cd}, \mathrm{Mn}$ and $\mathrm{Fe}$, belonging to the group of so-called heavy metals.

- The concentrations of these metals in aqueous solutions (leached with distilled water).

- Assessment of an environmental threat posed by the landfill to the surrounding soils, groundwater and surface waters.

\section{MATERIAL AND METHODS OF STUDY}

Samples were collected from the landfill located in Grunwaldzka Street, where all waste types generated by coal mining and cleaning in the Siersza mine had been disposed of till 2001 (Fig. 1). The mine exploited coal seams belonging to the Łaziska Beds [Dembowski, Unrug 1970; Williamson et al. 2006] and the accumulated waste cover a surface of about $14 \mathrm{~km}^{2}$. After the cessation of coal mining in 2001, the mass of waste was neither protected nor reclaimed for a long time. As a result, adjacent areas and watercourses have been contaminated, mainly by leaching the finest grain fractions from the landfill. For instance, the impact of mercury and some other elements on the water and soil environments was dealt with by Klojzy-Karczmarczyk and Mazurek $(2010,2014)$. In the surface part of the landfill, natural succession has taken place [Woch et al. 2013] and currently the site has already its top part reclaimed.

The samples were collected in an irregular grid, because of no clear-cut limits of the landfill site and the presence of stagnant water pools (Fig. 1). The depth of sampling was 1.5-2.0 m below the surface area using an Akkerman's core sampler with a diameter of $70 \mathrm{~mm}$ and depended on the landfill relief. Three major sampling fields were distinguished: western (W), central (OS) and south-eastern (ES) sections, while the northern slope of the landfill was the fourth (SK). A total of 21 samples were collected, each with a weight of 1.0-1.5 kg. The samples were averaged and reduced to obtain laboratory subsamples with a mass of about $20 \mathrm{~g}$, next dried at $105^{\circ} \mathrm{C}$ and ground to $<0.5 \mathrm{~mm}$. The total contents of $\mathrm{Zn}, \mathrm{Pb}, \mathrm{Cd}, \mathrm{Fe}$ and $\mathrm{Mn}$ were determined with X-ray fluorescence spectroscopy (XRF) using an Olympus $\mathrm{X}-5000$ analyser. The analysis of water leachates was conducted according to the standard PN-EN 12457-4: 2006 at a solid to liquid ratio of $1: 10$. The following parameters were determined: $\mathrm{pH}$ using the potentiometer method (standard PN-ISO 9280: 2002), the sulphate content using the gravimetric method (standard as above) and the content of selected metals using atomic absorption spectroscopy AAS with a ThermoScientific iCE 300 spectrometer (standard PN-ISO 8288: 2002).

\section{RESULTS AND DISCUSSIONS}

Samples are highly variable with respect to their petrographic character. They include prevailing fragments of sandstones and compact mudstones, accompanied by shales and coal. The content of pyrite has been evaluated in hand specimens at around $2-5 \%$, which is similar to the content of the exploited coal layers [Janeczka, Galos 2007]. The field inspection has also revealed a presence of slag of an unknown origin, mainly in the western part of the dumping ground.

\section{Total content of the selected elements}

The total content of the investigated metals considerably vary among the four sites (Table 1, Fig. 1). The maximum contents of $\mathrm{Zn}, \mathrm{Mn}$ and $\mathrm{Cd}$ occur in the western part: $\mathrm{Zn}$ in the range from 0.64 to $3.3 \%$ by weight, $\mathrm{Mn}$ from 0.46 to $34 \mathrm{mg} \cdot \mathrm{kg}^{-1}$, while the average content of $\mathrm{Cd}\left(3.8 \mathrm{mg} \cdot \mathrm{kg}^{-1}\right)$ is over three times higher than its average in the remaining parts $\left(1.1 \mathrm{mg} \cdot \mathrm{kg}^{-1}\right)$. The presence of a slag in the western part of the landfill was quite unexpected; its volumes reach $10 \%$ and its origin is not known. There are no reports or literature data pertaining to the metallurgical waste having been disposed of at that site. This material can be a reason for the elevated concentrations of $\mathrm{Zn}, \mathrm{Cd}$ and $\mathrm{Mn}$. 
Table 1. Total content of selected elements in coal waste samples.

\begin{tabular}{|c|c|c|c|c|c|c|c|}
\hline \multirow{2}{*}{$\begin{array}{l}\text { Section of the } \\
\text { landfill }\end{array}$} & \multirow{2}{*}{$n$} & \multirow{2}{*}{ Parameter } & $\mathrm{Zn}$ & $\mathrm{Pb}$ & Mn & $\mathrm{Fe}$ & Cd \\
\hline & & & \multicolumn{5}{|c|}{$\left[\mathrm{mg} \cdot \mathrm{kg}^{-1}\right]$} \\
\hline \multirow[t]{2}{*}{ Central } & 6 & $\min .-\max$ & $0.006-0.373$ & $3.72-5.21$ & $0.51-1.48$ & $1.66-3.59$ & $1.06-1.14$ \\
\hline & & $\mathrm{x} \pm \mathrm{s}$ & $0.174 \pm 0.1$ & $4.46 \pm 0.6$ & $0.84 \pm 0.4$ & $2.65 \pm 0.8$ & $1.1 \pm 0.04$ \\
\hline \multirow{2}{*}{ South-east } & \multirow[t]{2}{*}{4} & $\min .-\max$ & $0.302-0.858$ & $0.51-0.84$ & $0.51-0.84$ & $7.03-38.0$ & $1.1-1.2$ \\
\hline & & $x \pm s$ & $0.586 \pm 0.3$ & $0.64 \pm 0.1$ & $0.64 \pm 0.14$ & $16.3 \pm 6.2$ & $1.1 \pm 0.04$ \\
\hline \multirow[t]{2}{*}{ West } & 8 & $\min .-\max$ & $6368-33471$ & $3.45-4.55$ & $0.46-34.5$ & $1.23-33.2$ & $1.7-8.8$ \\
\hline & & $x \pm s$ & $23741 \pm 8599$ & $4.19 \pm 0.4$ & $15 \pm 13$ & $7.4 \pm 11.4$ & $3.8 \pm 2.6$ \\
\hline \multirow{2}{*}{ North slope } & \multirow[t]{2}{*}{3} & $\min .-\max$ & $1.349-2.316$ & $5.05-5.18$ & $0.71-6.01$ & $14.2-44.3$ & $1.21-1.25$ \\
\hline & & $\mathrm{x} \pm \mathrm{s}$ & $1.577 \pm 0.6$ & $5.14 \pm 0.1$ & $23.55 \pm 3$ & $25.2 \pm 16$ & $1.23 \pm 0.02$ \\
\hline \multirow{3}{*}{ Totality } & \multirow{3}{*}{21} & $\min .-\max$. & $0.006-33471$ & $3.45-5.2$ & $0.46-34.5$ & $1.23-44.3$ & $1.06-8.8$ \\
\hline & & $\mathbf{x} \pm \mathbf{s}$ & $9044 \pm 12862$ & $4.31 \pm 0.6$ & $6.44 \pm 10.5$ & $10.3 \pm 13$ & $2.16 \pm 2$ \\
\hline & & $v$ & 1.6 & 0.13 & 1.59 & 1.22 & 0.92 \\
\hline
\end{tabular}

$x$ - arithmetic average; s- standard deviation, $V$ - coefficient of variability $(s / x), n$ - number of samples

In the north slope of the dump, the amounts of $\mathrm{Pb}$ (mean $5.14 \mathrm{mg} \cdot \mathrm{kg}^{-1}$ ) are higher than in the remaining parts. By contrast, the total contents of the remaining four elements are the lowest in the south-east field.

Samples from the south-eastern part (field ES, Fig. 1) show similar contents of heavy metals in relation to samples from other parts. The exception is the sample ES/2, containing a high of $38 \mathrm{mg} \cdot \mathrm{kg}^{-1} \mathrm{Fe}$. However, the highest contents of Fe $\left(44.3 \mathrm{mg} \cdot \mathrm{kg}^{-1}\right)$ characterise the north slope of the dump (samples SK, Fig. 1).

The samples are highly variable in terms of their elemental composition. The largest coefficients of variation are for $\mathrm{Zn}$ and $\mathrm{Mn}(V=1.6)$, slightly lower for $\mathrm{Fe}(V=1.2)$ and $\mathrm{Cd}(V=0.9)$, and the lowest for $\mathrm{Pb}(V=0.1)$. Undoubtedly, the results depend closely on the petrographic diversity of the material accumulated. Pasieczna et al. (2008) reported on high concentrations of Zn, $\mathrm{Pb}$ and $\mathrm{Cd}$ in soils in the area of Trzebinia and explained it by a vertical superposition of the coal (Carboniferous, Siersza mine) and $\mathrm{Zn}-\mathrm{Pb}$ (Triassic, Trzebionka mine) deposits. In our opinion, the waste with high $\mathrm{Zn}, \mathrm{Mn}$ and $\mathrm{Cd}$ contents disposed of by the coal mine in the western section of the landfill had to be mixed with waste generated either by mining or processing of $\mathrm{Zn}-\mathrm{Pb}$ ores. Considering the presence of the slag, the more probable is the second supposition about an impact of metallurgy on high $\mathrm{Zn}$ and $\mathrm{Cd}$ values, but steel metallurgy cannot be excluded (high Mn content).

\section{Reaction and sulphate contents of water extracts}

The $\mathrm{pH}$ values of the water extracts range from 5.72 to 6.35 (Table 2), indicating a slightly acidic reaction of the leachates. The lowest averaged $\mathrm{pH}$ value equal to 5.79 has been calculated for the set of SK samples from the northern slope of the landfill, whereas the highest averaged $\mathrm{pH}$ value equal to 6.30 for the set of ES samples, taken in its south-eastern part.

The Regulation of the Minister of the Environment (2014) on the conditions to be met when disposing of effluents into water or
Table 2. $\mathrm{pH}$ and sulphate content in coal waste samples.

\begin{tabular}{|c|c|c|c|c|}
\hline $\begin{array}{l}\text { Section of } \\
\text { the landfill }\end{array}$ & $\mathrm{n}$ & Parameter & $\mathrm{pH}$ & $\begin{array}{c}\mathrm{SO}_{4}^{2-} \\
\left(\mathrm{mg} \cdot \mathrm{dm}^{-3}\right)\end{array}$ \\
\hline \multirow{2}{*}{ Central } & \multirow{2}{*}{6} & $\min .-\max$ & $5.87-5.99$ & $220-234$ \\
\hline & & $x \pm s$ & $5.93 \pm 0.04$ & $230 \pm 7.2$ \\
\hline \multirow[b]{2}{*}{ South-east } & \multirow{2}{*}{4} & $\min .-\max$ & $6.23-6.35$ & 219-311 \\
\hline & & $x \pm s$ & $6.30 \pm 0.06$ & $249 \pm 46.9$ \\
\hline \multirow[b]{2}{*}{ West } & \multirow{2}{*}{8} & $\min --\max$ & $5.98-6.2$ & 238-294 \\
\hline & & $x \pm s$ & $6.07 \pm 0.07$ & $256 \pm 28.6$ \\
\hline \multirow{2}{*}{ North slope } & \multirow{2}{*}{3} & $\min .-\max$ & $5.72-5.84$ & 214-252 \\
\hline & & $x \pm s$ & $5.79 \pm 0.06$ & $237 \pm 19.1$ \\
\hline \multirow{2}{*}{ Totality } & \multirow{2}{*}{21} & $\min .-\max$. & $5.72-6.35$ & $214-311$ \\
\hline & & $x \pm s$ & $6.02 \pm 0.06$ & $243 \pm 25$ \\
\hline
\end{tabular}

$\mathrm{x}$ - arithmetic average; s- standard deviation, $n$ - number of samples

soils and on the substances particularly harmful to the aquatic environment defines that the reaction of such discharges into the environment must be within the range 6.5-9.0. As the $\mathrm{pH}$ of all the samples is below the lower permitted value, adequate measures should be introduced by the landfill management to ensure proper parameters of the effluents infiltrating into the environment.

The highest content of sulphates $\left(311 \mathrm{mg} \cdot \mathrm{dm}^{-3}\right)$ was found in the water extract $\mathrm{ES} / 2$ (Table 2). The highest averaged $\mathrm{SO}_{4}{ }^{2-}$ content $\left(256 \mathrm{mg} \cdot \mathrm{dm}^{-3}\right)$ has been calculated for the $\mathrm{W}$ sampling field and the lowest $\left(230 \mathrm{mg}^{-\mathrm{dm}^{-3}}\right)$ for the OS field. High sulphate contents (214-311 $\left.\mathrm{mg} \cdot \mathrm{dm}^{-3}\right)$ leached from the waste samples indicate a possible threat of a substantial acidification of the waters and soils around the landfill. With regard to the Regulation of the 
Table 3. The concentration of selected elements in water extracts from coal waste samples.

\begin{tabular}{|c|c|c|c|c|c|c|c|}
\hline \multirow{2}{*}{ Section of the landfill } & \multirow{2}{*}{$n$} & \multirow{2}{*}{ Parameter } & $\mathrm{Zn}$ & $\mathrm{Pb}$ & $\mathrm{Mn}$ & $\mathrm{Fe}$ & Cd \\
\hline & & & \multicolumn{5}{|c|}{$\left[\mathrm{mg} \cdot \mathrm{dm}^{-3}\right]$} \\
\hline \multirow[t]{2}{*}{ Central } & 6 & $\min .-\max$ & $0.01-0.33$ & $2.23-2.51$ & $0.37-1.02$ & $0.69-1.44$ & $0.52-0.60$ \\
\hline & & $x \pm s$ & $0.16 \pm 0.15$ & $2.36 \pm 0.11$ & $0.61 \pm 0.24$ & $1.07 \pm 0.32$ & $0.56 \pm 0.01$ \\
\hline \multirow[t]{2}{*}{ South-east } & \multirow[t]{2}{*}{4} & $\min .-\max$ & $0.27-0.77$ & $2.22-2.43$ & $0.37-0.62$ & $3.02-15.98$ & $0.58-0.59$ \\
\hline & & $x \pm s$ & $0.51 \pm 0.22$ & $2.35 \pm 0.11$ & $11.91 \pm 9.84$ & $2.46 \pm 3.99$ & $1.83 \pm 1.08$ \\
\hline \multirow[t]{2}{*}{ West } & 8 & $\min .-\max$ & $3820-25103$ & $1.76-2.43$ & $0.42-22.44$ & $0.35-11.61$ & $0.85-3.69$ \\
\hline & & $x \pm s$ & $16818 \pm 6394$ & $2.22 \pm 0.19$ & $11.91 \pm 9.84$ & $2.46 \pm 3.98$ & $1.83 \pm 1.08$ \\
\hline \multirow[t]{2}{*}{ North slope } & 3 & $\min .-\max$ & $0.69-1.21$ & $2.49-2.34$ & $0.64-4.51$ & $4.26-13.74$ & $0.64-6.65$ \\
\hline & & $x \pm s$ & $0.95 \pm 0.26$ & $2.55 \pm 0.08$ & $1.94 \pm 2.22$ & $7.83 \pm 5.16$ & $0.65 \pm 0.01$ \\
\hline \multirow{3}{*}{ Totality } & \multirow{3}{*}{21} & $\min .-\max$ & $0.01-25103$ & $1.76-2.64$ & $0.37-22.44$ & $0.35-15.98$ & $0.52-3.69$ \\
\hline & & $x \pm s$ & $6727 \pm 9301$ & $2.33 \pm 0.17$ & $5.08 \pm 8.05$ & $3.63 \pm 4.59$ & $1.06 \pm 0.87$ \\
\hline & & V & 1.35 & 0.07 & 1.54 & 1.24 & 0.82 \\
\hline \multirow{2}{*}{\multicolumn{3}{|c|}{ Permissible level in leachates * }} & \multicolumn{5}{|c|}{$\left[\mathrm{mg} \cdot \mathrm{dm}^{-3}\right]$} \\
\hline & & & 2.0 & 0.5 & - & 10.0 & $0.4^{d} ; 0.2^{m}$ \\
\hline
\end{tabular}

$\mathrm{x}$ - arithmetic average; $\mathrm{s}$ - standard deviation, $V$ - coefficient of variability $(\mathrm{s} / \mathrm{x}), n$ - number of samples

*Due to Regulation of Environmental Ministry (Dz.U. 2014 poz. 1800), "-"luck data, ${ }^{d}$ per day, ${ }^{m}$ per month

Minister of the Environment (2014) that stipulates $500 \mathrm{mg} \cdot \mathrm{dm}^{-3}$ as the maximum concentration of $\mathrm{SO}_{4}{ }^{2-}$ in the leachates entering the environment, the values determined in this study have been below this limit. The authors' results coincide with those presented by Pasieczna et al. [2008]. The research done by Klojzy-Karczmarczyk and Mazurek in 2014 showed a sulphur content up to 14 times larger than in the presented data. The differences arise from the depth of sampling, which was 20-30 and $40-70 \mathrm{~cm}$ below ground level, as reported by the authors.

\section{The concentration of selected metals in water extract}

The Regulation of the Minister of the Environment (2014) also determines the contents of heavy metals and other substances that can be introduced into the environment during a day or a month. The concentrations of the five selected metals in water extracts (Table 3 ) have been referred just to such a case.

Manganese and zinc occur in most of the water extracts the western part of the landfill. It is impossible to assess the potential environmental impact of manganese (its concentrations range from 0.37 to $22.44 \mathrm{mg} \cdot \mathrm{kg}^{-1}$ ) as the "Regulation..." does not provide the respective limits. The concentrations of zinc that cover the range $3820-25,103 \mathrm{mg} \cdot \mathrm{kg}^{-1}$ are most troublesome if compared with the limit $2 \mathrm{mg} \cdot \mathrm{dm}^{-3}$ in effluent discharges in Poland. The limit has been exceeded from around 1700 to 12,500 times and this part of the landfill represents a serious environmental threat. The $\mathrm{Zn}$ concentrations in the water extracts from the solid samples collected in the remaining sampling fields (OS, ES and SK) do not exceed the limit.

The permitted lead content of effluents is set at $0.5 \mathrm{mg} \cdot \mathrm{dm}^{-3}$, while the water extracts have their $\mathrm{Pb}$ concentrations from 1.72 to $2.67 \mathrm{mg} \cdot \mathrm{dm}^{-3}$. Also these values exceed from 3.5 to 5.5 times the limit stipulated by the "Regulation..." and point to a substantial environmental threat of the whole coal waste dump.

In the case of $\mathrm{Cd}$, the legislator has specified its permitted contents $0.4 \mathrm{mg} \cdot \mathrm{dm}^{-3}$ in a daily discharge and $0.2 \mathrm{mg} \cdot \mathrm{dm}^{-3}$ in a monthly discharge. Both values have been exceeded in the current study two to three times (monthly rates) and from 1.5 to even 9 times (daily rates)

The permissible total $\mathrm{Fe}$ content in the effluents has been established by regulators at $10 \mathrm{mg} \cdot \mathrm{dm}^{-3}$. Of all the samples, only three $(E S / 2, W / 2$ and $S K / 3)$ slightly exceed the permissible limit, as their leachate concentrations are 15.98, 11.65 and 13.74 $\mathrm{mg} \cdot \mathrm{dm}^{-3}$, respectively.

The highest variation coefficients have been determined for $\mathrm{Mn}(V=1.54), \mathrm{Zn}(V=1.35)$, Fe $(V=1.24)$ and $\mathrm{Cd}(V=0.82)$. The smallest by far is the coefficient of $\mathrm{Pb}(V=0.07)$. The coefficients indicate a substantial diversity of the waste materials.

\section{Leachability of the selected metals}

An assessment of the leachability of $\mathrm{Zn}, \mathrm{Pb} \mathrm{Cd}, \mathrm{Mn}$ and $\mathrm{Fe}$ from the material accumulated on the coal mine dump in Trzebinia was made by relating the metal concentrations in the laboratory water extracts to the total contents of these elements in the laboratory solid samples (Table 4). The data expressed as the arithmetic means for all 21 samples indicate that the most prone to leaching are $\mathrm{Mn}$ and $\mathrm{Zn}$, removed into the eluates in 78 and $77 \%$, respectively. They are followed by $\mathrm{Pb}$ and $\mathrm{Cd}$, which were leached in approximately $50 \%$. The lowest was the leaching of $\mathrm{Fe}$, whose $36 \%$ was water-mobilised. A leachate from the central sampling area showed the highest single result $-88 \%$ of the 
Table 4. Share (\%) amounts of elements eluted from coal waste samples in relation to the total content.

\begin{tabular}{|c|c|c|c|c|c|c|c|}
\hline $\begin{array}{l}\text { Section of the } \\
\text { landfill }\end{array}$ & $n$ & Parameter & $\mathrm{Zn}$ & $\mathrm{Pb}$ & Mn & $\mathrm{Fe}$ & Cd \\
\hline \multirow[b]{2}{*}{ Central } & \multirow{2}{*}{6} & $\min .-\max$ & $72-100$ & $48-60$ & $69-85$ & $39-42$ & $46-54$ \\
\hline & & $x$ & 88 & 54 & 74 & 41 & 50 \\
\hline \multirow[b]{2}{*}{ South-east } & \multirow{2}{*}{4} & $\min .-\max$ & 78-91 & $62-65$ & $72-81$ & $37-43$ & $49-53$ \\
\hline & & $x$ & 87 & 63 & 76 & 40 & 51 \\
\hline \multirow[b]{2}{*}{ West } & \multirow[b]{2}{*}{8} & $\min .-\max$ & $58-85$ & $48-60$ & $69-92$ & $28-37$ & $42-56$ \\
\hline & & $x$ & 70 & 53 & 83 & 32 & 50 \\
\hline \multirow[b]{2}{*}{ North-slope } & \multirow{2}{*}{3} & $\min .-\max$ & $52-70$ & $48-51$ & $72-89$ & $30-32$ & $52-53$ \\
\hline & & $x$ & 62 & 50 & 79 & 31 & 52 \\
\hline \multirow{2}{*}{ Totality } & \multirow{2}{*}{21} & $\min .-\max$ & $52-100$ & $48-65$ & $69-92$ & $30-43$ & $42-56$ \\
\hline & & $x$ & 77 & 55 & 78 & 36 & 51 \\
\hline
\end{tabular}

$x$ - arithmetic average; $n$ - number of samples

total $\mathrm{Zn}$, whereas as many as $83 \%$ of the total $\mathrm{Mn}$ was in the water extracts from the western field. The release of such high amounts of metals entails a serious environmental threat to soils and waters in the vicinity of the landfill.

\section{CONCLUSIONS}

The most important findings and explanations are as follows:

1. The degree of leaching $\mathrm{Zn}, \mathrm{Pb}, \mathrm{Cd}$ and $\mathrm{Mn}$ from the waste generated by coal mining is substantial. The $\mathrm{Cd}$ and $\mathrm{Pb}$ concentrations in the water extracts exceed from around 1700 to 12,500 times the permissible daily contents set in the Polish standards.

2. Especially hazardous are high $\mathrm{Zn}$ contents of the waste in the western part of the landfill. This section of the dump contains also slag fragments that can be a major source of zinc and indicate that various industrial waste materials were disposed of onto the landfill operated by the Siersza coal mine.

3. The contents of Fe only in three samples out of 21 exceed the limit set in the standard for effluents. Therefore, pollution

\section{REFERENCES AND LEGAL ACTS}

CZOP M., KAJDA-SZCZEŚNIAK M. 2013. Environmental impact of straw based fuel combustion. Archives of Environmental Protection, 39, 4: 71-80.

DEMBOWSKI Z., UNRUG R. 1970. Statistical analysis of cyclic sedimentation of łaziskie beds (Upper Silesian Coal Basin). PTG Annals, 1: 63-110.

GALOS K., SZLUGAJ J. 2014. Management of hard coal mining and processing waste in Poland. Gospodarka Surowcami Mineralnymi-Mineral Resources Managements. 30, 4: 51-64.

GUS-Central Statistical Office. Statistical yearbook of industry-Poland. 2015. Warsaw. of waters and soils with iron outside the landfill should rather be negligible.

4. The content of $\mathrm{SO}_{4}{ }^{2-}$ leached from the waste does not exceed the limit, but due to the mineral composition of the waste should be monitored.

5. The $\mathrm{pH}$ values of the laboratory waste extracts exceed the permissible limits. The landfill leached by rainwater is a source of the acid drainage entering nearby watercourses and groundwater.

Surprisingly, high amounts of the metals were leached with distilled water in the laboratory. They may be even higher in the landfill effluents because the solid waste are exposed to rainwater with an acid reaction. It is a disturbing observation in case of highly toxic metals $(\mathrm{Zn}, \mathrm{Cd}$ and $\mathrm{Pb})$ and an unexpected result when studying a landfill of the waste supposed to be generated only by coal mining operations. Anyway, the landfill represents a serious threat to the environment if left without more advanced reclamation measures. Therefore, the landfill itself and its effluents mobilised by infiltration of rainwater should be subject to continuous observations.

JURECZKA J., GALOS K. 2007. Niektóre aspekty ponownego zagospodarowania wybranych złóż zlikwidowanych kopalń węgla kamiennego w Górnośląskim Zagłębiu Węglowym. Polityka energetyczna 10, 2: 645-661.

KLOJZY-KARCZMARCZYK B., MAZUREK J. 2010. Rtęć w gruntach $w$ otoczeniu wybranych składowisk odpadów górnictwa węglowego. Polityka Energetyczna-Energy Policy Journal. 13, 2: 245-251.

KLOJZY-KARCZMARCZYK B., MAZUREK J. 2014. Badania zawartości rtęci i siarki w odpadach z obszaru nieczynnej hałdy odpadów górnictwa węgla kamiennego. Polityka Ekologiczna - Energy Policy Journal. 17, 4: 289-302. 
KOT-NIEWIADOMSKA A. 2013. Cr, Ni, Cu w środowisku gruntowym terenu poprzemysłowego Zakładów Metalurgicznych I „Trzebinia”. Prace i Studia Geograficzne. 51: 45-56.

PASIECZNA A. (RED.), LIS J., GŁOGOWSKA M., DUSZADOBEK A., WITKOWSKA A. 2008. Szczegółowa mapa geochemiczna Górnego Śląska 1:25 000. Arkusz Myślachowice M-34-63-B-d z objaśnieniami. PIG-PIB. Warsaw.

PN-EN 12457-4:2006 Charakteryzowanie odpadówwymywanie. Badanie zgodności w odniesieniu do wymywania ziarnistych materiałów odpadowych i osadów. Część 4: Jednostopniowe badanie porcjowe przy stosunku cieczy do fazy stałej $10 \mathrm{l} / \mathrm{kg}$ w przypadku materiałów o wielkości cząstek poniżej $10 \mathrm{~mm}$ (bez redukcji lub z redukcją wielkości).

PN-ISO 8288:2002 Water quality. Determination of Co, $\mathrm{Ni}, \mathrm{Cu}, \mathrm{Zn}, \mathrm{Cu}$ and $\mathrm{Pb}-M e t h o d s$ for atomic absorption spectrometry flame.
PN-ISO 9280:2002Water quality. Determination of the sulfate(VI). Gravimetric method of barium chloride.

Regulation of the Minister of the Environment of 18 November 2014 r. on the conditions that should be fulfilled by inserting wastewaters into water or soil, and on substances particularly harmful to the aquatic environment. (Dz.U. 2014 poz. 1800.).

WILLIAMSON J., GZYL G., FROLIK A., KUBICA J., KURA K. 2006. Model koncepcyjny głównego zbiornika wód podziemnych Tychy - Siersza w rejonie prawdopodobnego wpływu zatapiania byłej kopalni „Siersza”. Kwartalnik Górnictwo i Środowisko. 2/2006. 5- 22.

WOCH M., RADWAŃSKA M., STEFANOWICZ A. 2013. Flora of spoil heaps after hard coal mining in Trzebinia (southern Poland): effect of substratum properties. Acta Botanica Croatica. 72 (2): $237-256$. 